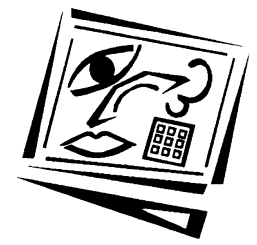

\title{
Using Web 2.0 to teach Web 2.0: A case study in aligning teaching, learning and assessment with professional practice
}

\author{
John Terrell, Joan Richardson and Margaret Hamilton \\ RMIT University
}

\begin{abstract}
Web 2.0 technologies have transformed the way people in information industries engage with their clients, collaborate on projects, promote their services and gather community knowledge. In this paper, we describe the impact of industry adoption of Web 2.0 technologies on an information management course. The students in this course are either already working in or plan to be entering information professions such as librarianship, archiving, records management, information architecture, and information and knowledge management. The lecturer and tutors for this course are changing the way learning is assessed and constructively aligning it with industry expectations for library and information graduates. Specifically in this paper we focus on the impact of the Web 2.0 affordances on student learning, the assessment process, and constructive alignment of intended learning outcomes with industry expectations in an information management blogging assignment. These findings are from the final stage of an Australian project where case studies of subjects that used Web 2.0 tools to assess student work were documented. Analysis of the students' blogs reveals exploration of the new tools used in a professional manner, greater collaboration and improved communication within the subject.
\end{abstract}

\section{Introduction}

Graduates entering information professions such as librarianship, archiving, records management, information architecture and information and knowledge management need to be good communicators, able to solve problems, familiar with the latest technologies, and be able to embrace, adopt and adapt them as required (Partridge, Lee \& Munro, 2010). Web 2.0 has changed the way people working in information industries engage with their clients. Many libraries, archives, galleries and museums use blogs and wikis to engage their visitors, to promote their services and to gather community knowledge. Social media applications have been developed that enable employees in an organisation to securely share ideas and knowledge and collaborate on projects. In this paper, we discuss how these changes have led to changes in the practices of learning and teaching information management.

The principle of constructive alignment (Biggs, 2003) suggests that for effective learning there needs to be an alignment between the intended learning outcomes, the student learning activities and the assessment tasks when curriculum is designed. This paper describes an assessment task in a postgraduate information management degree where students are expected to learn about the Web 2.0 environment and its potential for professional use. They do this by using a series of Web 2.0 tools and documenting 
their experiences and reflections in a Web 2.0 tool (a blog). The assessment criteria reflect the affordances of the Web 2.0 medium. It is argued that the student postings in their blogs provide rich evidence of their progress toward developing the skills, knowledge and attributes required by information professionals in a world of rapid technological change, and that this evidence demonstrates constructive alignment between the course learning objectives, the student learning activities, the assessment criteria and the requirements of professional practice. The design of curriculum using a constructive alignment approach is validated.

\section{Web 2.0 and the information management professions}

The term 'Web 2.0' is generally used to describe a broad range of software and services such as blogs, wikis, social networking tools, newsfeeds, sites for sharing media such as video and photographs, and many more. Many commercial websites incorporate 'Web 2.0' features such as user comments or forums, rating of products or services, and the ability to share content via a range of social media tools. Contributors to Wikipedia, itself one of the key exemplars of Web 2.0, associate the term Web 2.0 with 'web applications that facilitate participatory information sharing, interoperability, user-centred design, and collaboration on the World Wide Web' (Web 2.0, 2011). However the definition of Web 2.0 or even whether it exists is the subject of continual discussion (see, for example Talk: Web 2.0, 2011). The creator of the World Wide Web, Tim Berners-Lee, in a much quoted interview, describes Web 2.0 as 'a piece of jargon, nobody even knows what it means' (Laningham, 2006) and maintains that ideas of collaboration, interaction and participation have always underlain the development of the Web.

Tim O'Reilly visualised Web 2.0 as a set of principles and practices tying together 'a veritable solar system of sites' that demonstrate principles such as participation, user 'as' contributor, harnessing the power of the crowd and rich user experiences (O'Reilly, 2005). O'Reilly described seven of these principles, which Paul Anderson further adapted for the higher education environment when he identified six 'Big Ideas' that help explain the influence of Web 2.0. These are individual production and usergenerated content, harnessing the power of the crowd, data on an epic scale, architecture of participation, network effects, power laws and the long tail, and openness (Anderson, 2007, p. 14).

An Australian Learning and Teaching Council-funded project to develop good practice guidelines for the assessment of student learning using Web 2.0 identified five pedagogical affordances of Web 2.0 authoring: open publishing, new communication styles and texts, expressing personal identity and experience, co-creation and collaboration, and content management (Waycott, Gray, Clerehan, Hamilton, Richardson, Sheard \& Thompson, 2010). All of these opportunities were found to also present challenges, many of them relating to issues of intellectual property and academic integrity, student expectations and needs for privacy, and the reliance on software that was outside the control of the university.

The increasing reliance in the library and information management profession (commonly known as LIS, for library and information science) on information technology has led to educational programs in LIS becoming more technically demanding (Kules \& McDaniel, 2010). However Kules and McDaniel's study of 57 American LIS educational programs' expectations of new students showed that, while 
more than half $(54 \%)$ expected students would be able to use word processing software, and $42 \%$ expected familiarity with email, only $5 \%$ (3 programs) assumed knowledge of Web 2.0 or social networking (2010, p. 228). In recent years the concept of Library 2.0 has developed to describe the changes library services are undergoing in response to the evolution of Web 2.0 (Casey, 2005; Casey \& Savastinuk, 2006). These changes have included disseminating information via RSS feeds, creating blogs and forums to foster interaction among staff, members and visitors such as authors, etc., participation in collaborative community projects and allowing social tagging in the library catalogue.

Partridge, Lee and Munro (2010) documented the evolution of 'Librarian 2.0', seen as the 'library and information professional in a world of ever changing emerging technology' (p. 318). Their research drew on existing literature as well as data gathered from focus groups involving 81 Australian library and information professionals to provide 'the first empirically derived analyses of the key skills, knowledge and attributes of "Librarian 2.0" (p. 318). They identified eight key issues: technology, learning and education, research or evidence based practice, communication, collaboration and teamwork, user focus, business savvy, and personal traits (Partridge, Lee \& Munro, 2010). Perhaps the most popular and widespread method of developing Librarian 2.0 has been the Learning 2.0 or ' 23 Things' program originally developed by Helene Blowers at the Public Library of Charlotte Mecklenburg County, North Carolina (PLCMC, 2007). Released under a Creative Commons license, the program has been adopted and adapted by over 1000 libraries worldwide, from state and public libraries to university and special libraries (Blowers, 2009). In the original iteration, staff at PLCMC were encouraged to explore '23 Things' on the Web, such as wikis, RSS, Flickr, YouTube, etc. and report on them via personal blogs. Yarra Plenty Regional Library in Melbourne introduced the program to Australia in 2006 (Lewis, 2008) and it was rapidly adopted by public and university libraries.

Stephens and Cheetham (2011) used a national survey of 384 library staff in Australia who had participated in a Learning 2.0 program, combined with focus groups, to evaluate the impact and effect of Learning 2.0 programs in Australian academic libraries. As a result of their participation in a Learning 2.0 program, most staff reported increased comfort and greater confidence in learning about new technologies, greater inclination to explore new technologies and an increased focus on sharing and collaboration. However, significant rates of non-completion of the program were reported, particularly among staff who were less interested in new technologies or saw less relevance for them in their day to day work (Gross \& Leslie, 2010; Stephens \& Cheetham, 2011).

Learning 2.0 programs have been mainly used as an internal staff development mechanism within libraries and other information organisations. Anecdotal evidence collected by one of the authors suggests that libraries, particularly those where staff have undergone Learning 2.0 programs, expect new graduates to already have the associated skills. There may be some expectations that those in the 'digital native' demographic, e.g. born in the 1980s and later, are already familiar with the uses of recent web technologies such as Web 2.0. However several studies cast doubt not just on the existence of the digital native phenomenon, but also on the depth of their experience, knowledge and understanding of the technologies (Bennett, Maton \& Kervin, 2008; Kennedy, Judd, Churchward, Gray \& Krause, 2008). 
This suggests there is potential to incorporate a type of Learning 2.0 program into an educational program that prepares students for careers in the information professions. However no prior instances of this have been discovered, nor are any known to Helene Blowers (personal communication, 31 May, 2011). This paper describes one such project and shows how the student writings demonstrate their acquisition of capabilities required by new graduates entering the information professions.

\section{Constructive alignment and intended learning outcomes}

Several studies support the concept of aligning assessment with learning (Biggs, 2003; Henderson \& McWilliams, 2008; Ramsden, 1992). This constructive approach to learning fits well with the concept of assessment for learning, which means designing assessment tasks that aim to enhance learning (Ramsden, 1992).

In order to constructively align assessment tasks with learning, educators need to have a clear understanding of the intended learning outcomes they want students to achieve. In a professional discipline, such as information management, these intended learning outcomes will be driven by the capabilities that graduates are expected to have, both those specific to the profession - as outlined above - and generic graduate capabilities. The former Department of Education, Employment and Workplace Relations (DEST) published a report in 2002 identifying eight key generic skills: communication; team work; problem solving; initiative/enterprise; planning and organisation; self management; learning; and technology (DEST, 2002).

It is difficult to successfully align learning tasks with intended graduate outcomes and there has traditionally been a mismatch between what employers require and the employability skills of graduates. An earlier report funded by the former Department of Employment, Training and Youth Affairs (DETYA) titled Employer satisfaction with graduate skills (DETYA, 2000) noted that “... a large proportion of applicants for positions are considered unsuitable" (p. vii), identifying key skill deficiencies of graduates in the areas of oral business communication, creativity and flair, problem solving, independent and critical thinking, and understanding of business practice. Designing and implementing assessments that embed generic professional capabilities, academic theories and concepts as well as the capabilities required in a workplace are important. It is an imperative that students apply these skills in a real world industry setting. The ways generic skills cluster are strongly shaped by particular features of the context in which the work is carried out (Beckett \& Hager, 2002).

From this perspective, Web 2.0 may solve the constraints imposed by a traditional classroom. Students may alter their behaviour with the removal of face to face interaction, enabling the type of interactions required to communicate and build relationships to change. Professional skills acquired through completing a variety of tasks using Web 2.0 tools are needed for the workplace today. Many of the students use the tools for social networking in their personal lives, but need to build on this base to enable effective communication in the modern workplace. Research evidence suggests knowledge gained in the classroom does not become usable at work without further learning (Eraut, 2002). In our research we aimed to find out whether the Web 2.0 tools are enabling these students to be effective communicators both within the class, and in relation to their workplace and employability skills. 


\section{Method}

This research follows a case study method. Yin (2003) defines a case study as an empirical inquiry that investigates a contemporary phenomenon within its real life context, especially when the boundaries between phenomenon and context are not clearly evident. Case study methodology is particularly well-suited to the fields of information management and systems, where the focus is on organisational rather than technical issues (Benbasat, Goldstein \& Mead, 1987). The form and content of case studies vary greatly depending on the audience and context. The use of evidence from multiple sources is seen by Yin (2003) as the most significant attribute of case studies. McBurney (2001) on the other hand emphasises the individuality of each case or situation. Case studies may include information gathered from a single source or from a variety of sources including naturalistic observations, archival records and interviews with the case subject and with those who regularly interact with them.

The case study is interpreted in this paper using ideas drawn from the literature that recognise the need for pedagogy to be underpinned by constructive alignment (Biggs, 2003). It should be noted, however, that evidence to definitively support a hypothesis that Web 2.0 assessment predetermines students' capacity to collaborate and to construct meaning from what they have learnt is not available from this research to date. Students' abilities to utilise the generic skills acquired and to obtain professional employment have not been tested.

The lecturer for this course volunteered to become one of 17 pilot participants in an Australian Learning and Teaching Council (ALTC) funded research project entitled "Web 2.0 Authoring Tools in Higher Education Learning and Teaching: New Directions for Assessment and Academic Integrity". Ethics approval was obtained from all participating universities (Ethics ID: 0932185 University of Melbourne). Data was gathered about subject or course objectives and Web 2.0 assessment requirements from the academic and student perspectives, throughout semester 1, 2010. This included examples of student work. The lecturer described the impact of Web 2.0 on student progress and students reflected on their learning throughout the semester.

Informed by Biggs' theory of constructive alignment, we have analysed examples of student work to show how they demonstrate student learning in line with the intended learning objectives. Our analysis also examines the suitability of the assessment criteria in demonstrating student learning.

The course learning objectives were underpinned by the findings of Partridge, Lee and Munro (2010) which demonstrate alignment of the course with the skills, knowledge and attributes required by information professionals into the future.

The examples of student work analysed were taken mainly from the final reflective posting in the assessment task, as this was where the students were asked to summarise their experiences, to reflect on how the assignment had helped them develop their skills and understanding of web technologies, as well as consider its relevance to their future careers as information professionals. Initial postings were also included in the analysis as these often provided evidence of the student's development over the course of the assignment. These were examined for evidence that the students had met each of the assessment criteria and hence the course learning objectives. Themes were identified under each of the assessment criteria and supported by quotations from the student work. 


\section{Case study}

\section{The course}

The assignment in this case study was called Web 2.0 Adventure and was developed from the Learning 2.0 program. It was part of the assessment for an introductory course (i.e. subject or unit) in technology for library and information management undertaken by students in the Master of Information Management program. The program prepares students for careers as information, document and records managers, librarians, archivists, teacher librarians, community information officers, database specialists, research and information analysts, in private industry, government and semi-government bodies, universities, schools and professional associations.

The course introduces students to the range of technologies used in information and knowledge management and the principles underlying the use of these tools to structure, create, store, retrieve, share and preserve information. The curriculum was designed to align learning activities and assessment tasks with learning outcomes. This process is absolutely crucial to effective delivery when the resources are drawn from a number of sources which could otherwise lead to serious fragmentation of the learning narrative. The design of the subject curriculum must include each topic, the associated method of delivery, and assessment. The additional task is the encasing professional context narrative. For this paper only one assessment task and its associated teaching activities, the Web 2.0 Adventure, are described as a means of illustrating the development approach employed.

The intended learning outcomes for the course are shown in Table 1. These are based on the University's graduate attributes which expect graduates to be 'Work-ready, Global in outlook and competence, Environmentally aware and responsive, Culturally and socially aware, Active and lifelong learners, and Innovative' (RMIT University, 2011). A close alignment is apparent between the course's intended learning outcomes and the required skills, knowledge and attributes identified by Partridge, Lee and Munro (2010). Some examples of this are shown in Table 1.

\section{Web 2.0 Adventure}

The Web 2.0 Adventure assessment task was adapted by the lecturer from the Learning 2.0 program to suit the academic requirements of the university program. This included restructuring the task from 23 weeks to 7, revising most of the activities and adding an assessment framework.

The students worked through an online tutorial over a period of seven weeks. Each week they carried out a number of activities which involved using the specific tools and investigating their capabilities. In regular blog postings they reflected on both their own experiences with the technologies and their actual or potential use in an information organisation.

The weekly schedule for this iteration of the course in 2010 was: week 1, introduction to Web 2.0, blogs and setting up your own blog; week 2, RSS feeds, wikis and collaborative content; week 3, microblogging including Twitter; week 4, social bookmarking; week 5, video, photos and other media; week 6, maps and mashups; week 7 , final reflection. 
Table 1: Intended learning outcomes and Librarian 2.0 skills, knowledge and attributes

\begin{tabular}{|c|c|}
\hline $\begin{array}{c}\text { Intended } \\
\text { learning outcomes }\end{array}$ & $\begin{array}{l}\text { Sample skills, knowledge and attributes required } \\
\text { by Librarian } 2.0 \text { (Partridge, Lee \& Munro, 2010) }\end{array}$ \\
\hline 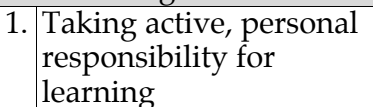 & $\begin{array}{l}\text { Learning and education - maintain own professional development, set } \\
\text { own goals. } \\
\text { Business savoy - good project management skills, manage time well. }\end{array}$ \\
\hline $\begin{array}{l}\text { 2. Using communication } \\
\text { and team working skills } \\
\text { to promote productive } \\
\text { and cohesive relations } \\
\text { among employees }\end{array}$ & $\begin{array}{l}\text { Technology - 'talk the talk' with IT professionals and managers. } \\
\text { Learning and education - willing to share knowledge with colleagues, } \\
\text { mentor and coach others. } \\
\text { Collaboration - work successfully as part of a team. } \\
\text { User focus - loves working with people. }\end{array}$ \\
\hline $\begin{array}{l}\text { 3. } \begin{array}{l}\text { Embracing problem } \\
\text { solving, initiative and } \\
\text { enterprise skills }\end{array}\end{array}$ & $\begin{array}{l}\text { User focus - look at things from user perspective, seek to actively use } \\
\text { emerging technologies to provide users with a voice. } \\
\text { Business savoy - lateral thinkers, can prioritise and problem solve. } \\
\text { Research based practice - gathering evidence, evaluating services. }\end{array}$ \\
\hline $\begin{array}{l}\text { 4. Applying technology } \\
\text { competently and } \\
\text { appropriately }\end{array}$ & $\begin{array}{l}\text { Technology - need to 'have a web presence', IT skills only part of it. } \\
\text { Learning and education - boundaries between IT and LIS professionals } \\
\text { narrowing, LIS skills \& knowledge becoming more complex. } \\
\text { Communication - use diverse formats and media. Excellent } \\
\text { presentation skills. }\end{array}$ \\
\hline $\begin{array}{l}\text { 5. Taking an open, } \\
\text { flexible, playful and } \\
\text { persistent approach to } \\
\text { work design, and a } \\
\text { benign attitude to error }\end{array}$ & $\begin{array}{l}\text { Learning and education - 'Librarian } 2.0 \text { has an inquiring mind, enjoys } \\
\text { playing and experimenting, and loves learning' (p. 326). Has latest } \\
\text { apps on home pc and is 'willing to explore and practice after the } \\
\text { workday has finished'. } \\
\text { Business savoy - willing to let go of the status quo, embrace change. } \\
\text { Personal traits - adaptable, flexible, persistent and resilient, willing to } \\
\text { move outside comfort zone, open mind, willing to try new things } \\
\text { and learn from failure. }\end{array}$ \\
\hline
\end{tabular}

The student's blog was assessed according to five criteria: participation, communication, execution, persistence and reflection. The assessment criteria were chosen to represent the main features of Web 2.0 and aligned with the course learning objectives:

- Participation reflected the degree to which students completed the activities including setting their own learning goals and working toward them. This reflected several of the 'big ideas' underlying Web 2.0 (Anderson, 2007, p. 14). The ideas of 'individual production and user generated content' and 'harnessing the power of the crowd' (pp. 14-16) rely on the willingness of large numbers of people to be producers as well as consumers of content, creating their own blogs, contributing to collaborative resources and uploading their own creative works for public use. This in turn contributes to the 'architecture of participation' (p. 19).

- Communication included the students' exploration of the potential of the tools for interaction and collaboration. Along with the proliferation of mobile phones and PDAs, Web 2.0 tools such as MySpace, Facebook, Skype and Twitter have changed the way people communicate. New tools for collaboration appear regularly and the assignment is adapted accordingly to take advantage of these. Students were encouraged to explore the ways these tools can be used, both personally and professionally, which often meant going outside their comfort zone.

- Execution assessed the students' expertise in using the technologies. This included their exploitation of the affordances of the blogging environment (embedding feeds, gadgets, media, formatting etc) and their use of the individual Web 2.0 tools 
e.g. editing a wiki, using Twitter and creating a Google map or a mashup. Expecting students to use the tools helped them develop the technical skills required to participate in the Web 2.0 environment.

- Persistence rewarded students' efforts and resourcefulness in using the tools and solving problems, regardless of the eventual success or otherwise. This recognised that students came to this assignment with very different levels of experience, background and computer skills. Students were expected to undertake activities that extended their existing skills rather than to document what they already knew or could do. Being able to stick at a task even when it is going disastrously, trying new strategies, learning from mistakes and seeking help are all vital attributes for participation in any career. It also reinforced the importance of participation regardless of expertise. Students who extended their existing skills by assisting others also gained marks under this category.

- Reflection assessed the depth and quality of the students' reflection on the processes they had undertaken, their achievement of their goals and on the relevance of these technologies to information management. This may encompass new technical skills, extension of their previous knowledge of tools into the area of professional use, understanding of the underlying ideas behind Web 2.0, increased confidence in dealing with challenges and solving problems, and greater appreciation of issues such as intellectual property rights, privacy, security and how to resolve them.

Table 2: Alignment of Intended learning outcomes, student activities and assessment criteria

\begin{tabular}{|c|c|c|c|}
\hline & $\begin{array}{c}\text { Intended } \\
\text { learning outcomes }\end{array}$ & $\begin{array}{c}\text { Sample student } \\
\text { learning activities }\end{array}$ & $\begin{array}{c}\text { Aligned } \\
\text { assessment criteria }\end{array}$ \\
\hline 1. & $\begin{array}{l}\text { Taking active, personal } \\
\text { responsibility for } \\
\text { learning. }\end{array}$ & $\begin{array}{l}\text { Set goals. } \\
\text { Choosing activities to undertake. } \\
\text { Demonstrate engagement with activities. }\end{array}$ & $\begin{array}{l}\text { Participation } \\
\text { Reflection }\end{array}$ \\
\hline 2. & $\begin{array}{l}\text { Using communication } \\
\text { and team working skills } \\
\text { to promote productive } \\
\text { and cohesive relations } \\
\text { among employees. }\end{array}$ & $\begin{array}{l}\text { Read and comment on each other's blogs. } \\
\text { Use Twitter to explore its use as a } \\
\text { communication medium. } \\
\text { Share resources using social bookmarking tools } \\
\text { such as Delicious, Diigo, Connotea. }\end{array}$ & $\begin{array}{l}\text { Communication } \\
\text { Execution } \\
\text { Reflection }\end{array}$ \\
\hline 3. & $\begin{array}{l}\text { Embracing problem } \\
\text { solving, initiative and } \\
\text { enterprise skills. }\end{array}$ & $\begin{array}{l}\text { Use a variety of approaches to solve problems. } \\
\text { Keep trying. } \\
\text { Ask for help from colleagues as appropriate. }\end{array}$ & $\begin{array}{l}\text { Execution } \\
\text { Persistence } \\
\text { Reflection }\end{array}$ \\
\hline 4. & $\begin{array}{l}\text { Applying technology } \\
\text { competently and } \\
\text { appropriately. }\end{array}$ & $\begin{array}{l}\text { Create and maintain a blog. } \\
\text { Edit a Wikipedia article. } \\
\text { Set up RSS feeds. } \\
\text { Create a custom Google map or a mashup using } \\
\text { Yahoo! Pipes (http: / / pipes.yahoo.com/). }\end{array}$ & $\begin{array}{l}\text { Execution } \\
\text { Reflection }\end{array}$ \\
\hline 5. & $\begin{array}{l}\text { Taking an open flexible, } \\
\text { playful and persistent } \\
\text { approach to work } \\
\text { design and a benign } \\
\text { attitude to error. }\end{array}$ & $\begin{array}{l}\text { Go beyond one's comfort zone. } \\
\text { Try new things even if you don't know if you } \\
\text { will succeed. } \\
\text { Treat errors as an opportunity to learn } \\
\text { something new. } \\
\text { Experiment and have fun. }\end{array}$ & $\begin{array}{l}\text { Participation } \\
\text { Communication } \\
\text { Persistence } \\
\text { Reflection }\end{array}$ \\
\hline
\end{tabular}

The alignment of the course learning objectives with student learning activities and assessment criteria is shown in Table 2. The assessment criterion of Reflection underlies all of the intended learning outcomes in that it assesses the students' ability to 
demonstrate via their blog writing their achievement of the other assessment criteria, and hence of the learning objectives.

Due to time constraints, the data analysed came from the 22 students in one of the three tutorial groups. As the analysis was qualitative in nature, it was felt that this group size was sufficient to demonstrate a range of ways in which student learning aligned with learning objectives. However, it is possible that analysis of a larger group would provide additional factors. Table 3 demonstrates that the sample class was reasonably representative of the class as a whole. A spread of ages was evident, from early twenties to late fifties. 13 of the 22 students in the sample group were in the 'digital native' demographic, being born since 1980; however it is outside the scope of this research to relate this to the findings.

Table 3: Cohort demographics

\begin{tabular}{|l|c|c|}
\hline & Sample class & Total class \\
\hline Number of students enrolled & 22 & 61 \\
\hline Male & 6 & 14 \\
\hline Female & 16 & 47 \\
\hline Mean age at 1 Mar 2010 (years) & 31.6 & 33.0 \\
\hline Median age (years) & 28.6 & 30.5 \\
\hline Local & 22 & 59 \\
\hline International & 0 & 2 \\
\hline Mean mark awarded & $75 \%$ & $75 \%$ \\
\hline Median mark awarded & $78 \%$ & $78 \%$ \\
\hline
\end{tabular}

\section{Results}

\section{Participation}

Students demonstrated a high level of engagement with the activities, showing evidence of taking active responsibility for their own learning. In their first postings, most students articulated goals for the entire project or for specific activities. These often focussed on investigating professional applications for the tools:

I am interested in what new tools I can discover from this project, my web-abilities are pretty superficial. I am looking forward to using these tools in an Information Management context. (student 16, first posting)

My next goal is to play around with the template and maybe add a picture of some kind for this blog. In general, I will be experimenting with the blog to see how this works and try to gain some skills in the field. (student 3, first posting)

They also commented on the newness of these activities, some expressing varying degrees of apprehension and excitement, whereas others wondered if they would learn anything new:

I embarked on this journey with trepidation, as I have said before in previous posts, because even though I wasn't totally computer illiterate, I didn't know a great deal about Web 2.0. (student 4, final posting)

I'm not a hugely technologically-inclined person, although I'm pretty familiar with most of the major web 2.0 applications (Wikipedia, Facebook, etc.), so it'll be interesting to see how this all goes! (student 14, first posting) 
I have to say, when I first got this assignment, I was unsure. How hard could it be? I know Web 2.0, I use Facebook and Wikipedia, what else can there be? Well, lots as it turns out. ... there are so many aspects of Web 2.0 that I simply knew nothing about before I started my explorations. From Social Bookmarking to mashups, this assignment has, at times, been a pretty steep learning curve! (student 14, final posting)

Many students expressed the enjoyment they experienced in exploring new web tools, a key learning objective of the course:

I've been having a little too much fun playing around with all the web 2.0 features available such as different widgets, themes, and headers and possibly wasting valuable theoretical thinking time. (student 18, first posting)

This assignment has been enjoyable and at times a distraction from other things! I have found myself wanting to check my blog regularly and it has been rather addictive! (student 5, final posting)

Students exhibited incremental learning each week, evidence that the constructive alignment approach to curriculum design was successful:

As the weeks went by I was developing new skills and abilities to join a new technology, explore it, play with it, research it, test it, develop opinions about it, share it with my buddy group and review it. (student 3 , final posting)

Some students recognised that they had embarked on a process of continual learning:

I know that although it is the end of the assignment,... this is not the end of my adventure per se, for I intend to continue learning about these technologies and tools for a long time to come. (student 4 , final posting)

I'm actually going to keep up the blog and continue working through areas I'm a bit shaky on and posting about them. I'm also going to keep an eye on other people's blogs. I've enjoyed this assignment so much! (student 12, final posting)

\section{Communication}

Although the assignment was assessed individually, students formed teams or 'buddy groups' with three or four colleagues. This provided a relatively non-threatening environment in which to read and comment on each other's work, to explore the communication and collaboration possibilities of the tools, and to work together to resolve problems.

Students commented on the advantages of working in teams, while some also found support among the wider class:

Knowing my team mates had to follow me kept me accountable in staying up to date with the various tasks. It's been great to check out what other team-mates are doing: and ___'s polls inspired me to have a go at adding my own, whilst___'s encouraging words were always welcome. (student 5 , final posting)

It's been great following everyone's experiences, watching people flounder (like myself), help each other out and engage on each other's blogs. (student 14, final posting)

Also, thank you to the other people outside my group for following me and commenting on my posts. These are other students from my tutorial and the other tutorial, as well as some online students. I have learned from you and enjoyed following your blogs also. (student 4 , final posting) 
Not all aspects of the experience were positive:

Blogging about my ups and downs became a way of sharing a load with my buddies, however, I do find reading other people's blogs extremely tiring and time devouring. (student 10, final posting)

Some students showed great playfulness and creativity in their exploration of communication possibilities even if they ended up preferring familiar methods:

Twitter was a rubbish way to communicate in our group - but loads of fun. My idea to Twitter only in Haikus was, well, really ineffective - I don't recommend it. We found email the most effective way to stay in touch. (student 5, final posting)

\section{Execution}

Much of the evidence of students' technical capabilities was apparent in the creation of their blogs and their success in embedding feeds and other media. They also reported on their developing skills.

Some students were amazed at their achievements and their increase in technical prowess:

It has been extremely rewarding and encouraging for me to discover all of these tools and I can't believe how much I have expanded my vocabulary! I love shocking my husband and kids when I talk about the meaning of http, HTML, URL, mashups, pipes, etc. I never dreamed I'd be Tweeting, Facebooking and uploading videos and photos on to YouTube and Flickr and embedding them in my very own blog! (student 4 , final posting)

I look back and can't believe I managed to do half the stuff I did with these web 2.0 technologies. I know that even though I was not always hitting the right mark with my results or reviews, I did learn something new and opened new doors to technologies and tools of the 'now' and 'future'. (student 3, final posting)

Others found that their explorations led them to develop skills and knowledge in related areas:

I found that getting to know new sites, reading, searching for solutions, tweaking my blog - would literally eat away hours at a time. However, if at the very start of this adventure every techno-hiccup was a problem of epic proportions, searching the net for solutions is like a breeze now. I guess this adventure has made me not only more confident about using new technology, but at the same time has opened my eyes to the wealth of information that is accessible through the web. (student 10, final posting)

Most students were already aware of some or all of the technologies, but some recognised that in order to understand the technologies and their potential, they had to actually use them, one of the elements of lifelong experiential learning:

While I was already aware of all the web services we've used throughout the assignment before it started, I didn't necessarily have a comprehensive knowledge about them. But more importantly, I didn't necessarily have * practical* experience with them. And this is the key thing that has been useful to me during this assignment - putting the conceptual knowledge I have about Web 2.0 into practice. (student 13, final posting) 


\section{Persistence}

Many of the students exhibited great application in persevering with tasks even when the difficulties seemed insurmountable. Some reported how this had helped them gain confidence, learn new skills or even just complete the assignment:

I kept hitting stumbling blocks and finding problems. I had to fix that problem only to discover another one. Even though a lot of the resources I worked with throughout these 6 weeks took some time to figure out, I enjoy the challenge and enjoyed working through to find a solution. Often I found a solution or pathway that I didn't know existed before (i.e. like Slideshare) and was able to expand my skills. (student 8, final posting)

I found the assignment to be like climbing a small mountain. It was a little mountain of work. I was inexperienced at climbing the mountain to start with, but I found Blackboard, help searches and my group and tutor to be my guide and taking things week by week got me experience in the tools and got me to the top. I experienced a little bit of fogginess on the climb (with embedding a video in my blog, uploading a video of my own and creating a Google map), but I kept on keeping on, and things became clear and manageable. (student 19, final posting)

For others the very existence of this criterion provided encouragement:

Having persistence as one of the key criteria has been really encouraging: I always knew, when I was getting really frustrated by a piece of technology that wasn't working how I anticipated that it would, that my blogging about how hopeless the task seemed would not (necessarily) reflect badly on my final mark - so I felt I could be really honest when I was struggling. (student 5, final posting)

\section{Reflection}

The reflection criterion underlay all of the other assessment criteria in that their achievement of these was demonstrated by their ability to reflect throughout their blogs on what they had done.

In the final week of the assignment students were also asked to sum up their experiences in a final blog posting indicating how they felt the assignment had helped them develop new skills and understanding of new web technologies. This also encompassed feedback on the suitability of the activities for their pre-existing skill levels, the amount of time required, and suggestions about improvements for future years. They were also asked how relevant the assignment had been for their current or future careers as information professionals.

Many students commented on the difficulty of gaining familiarity with several new technologies each week and with the amount of time this required, although some also acknowledged the potential of these tools for distraction and reinforcing inefficient work practices:

As for this Blog assessment task: well, I loved it, and I hated it. Because so many of these technologies were so new to me ... I felt like I had to rush so quickly to get a grip on them, which didn't leave much time to really process and use and review what I was doing, which meant that by the time I'd figured out what an RSS was and how to set up and organise feeds, suddenly I was behind in my reading on Social 
Bookmarking, and on it went, and then suddenly it was all due! (student 1, final posting)

A week is not long enough to explore a Web 2.0 Technology if you have never used it previously. It has taken me about 2 weeks to grasp the ideas and aims of some services. (student 2 , final posting)

For completing homework tasks in each week I had to explore these tools which was very time consuming, especially for someone like me who isn't tech savvy. (student 11, final posting)

For many students there was a great sense of satisfaction in overcoming difficulties. This in turn left them with greater confidence to tackle the technological environment:

Although creating the blog was frustrating at times, on the whole, it was rewarding. I felt a great sense of achievement from successfully carrying out the tasks (student 6, final posting)

Creating my own blog which was unthinkably difficult in the very beginning, I nevertheless overcame the initial reluctance to engage and the new discoveries made along the way became addictive. Everything from embedding to creating maps, to discovering mashups and pipes - was tremendously inspiring and made me understand the importance of technical skills in the current employment market. (student 10, final posting)

Many students showed evidence of having thought about the role of technology in relation to people, showing awareness of contradictions between their own philosophies and their uses of technology:

Technology is undoubtedly changing us and the way we live. And although I've been admiring the social aspects of using Web 2.0 tools and the way it enables people to communicate and connect across the world according to their areas of expertise or interest, I can't help but notice the reverse side of this technological dependence - we're also risking alienation in some way. As we spend more time glued to our computer screens, there's less time to engage in the real, physical way with people around us. Nevertheless, the brave new world is on our doorstep, and we can either chose to join it or to ignore it. Ignoring it, I feel would make one's fate not too dissimilar to that of the dinosaurs! I guess I'm choosing to open the door! (student 10, final posting)

Most students saw relevance for their future careers in the investigations they had undertaken:

In the past few years a lot of managers I have come into contact with have talked about Web 2.0 (not that I knew it at the time) with an air of panic. If I keep up my skills, and keep one hand in these tools, I think that I will have a lot of talking points to get noticed by employers. (student 7 , final posting)

I definitely think this assignment is relevant to my future as an information professional. Any glance at lists of library jobs available these days will show that employers in this area of work are increasingly seeking out people who are proficient at technology and web skills. There are even entirely new categories of jobs being created such as "emerging technologies expert" and such things, which I think is quite exciting. To be honest, I really hope I'll get to use these types of skills in a future job. It's one of the things that makes information management appealing to me.' (student 13, final posting) 


\section{Discussion}

The assignment exploited to varying degrees the affordances of the Web 2.0 environment as identified by Waycott et al. (2010). Open publishing using the freely available Blogger and Wordpress blogging environments made it easier for students to personalise their blogs by embedding media, adding feeds and widgets, than would have been possible within the more restrictive learning management system. Students were able to control their privacy settings to allow feedback by their colleagues and to share their findings, problems and solutions.

The range of communications media available allowed students to investigate the strengths and weaknesses of each medium for activities such as announcements, organising work, soliciting feedback, creating documents, providing emotional support or just chatting. Students used options for expressing personal identity by creating blog personas that were separate from their official student life, ranging from pen names to roles such as space travellers or literary characters. The examples of student writing in the results section above demonstrate the informal yet authentic voice developed by some students.

Tools for co-creation and collaboration were investigated, sometimes amongst class members, such as using Google docs to create a presentation for another class. Many students also experienced collaboration with the wider community, by contributing to Wikipedia articles, or participating in Twitter conversations. The affordance of content management was apparent in the way students were able to combine content from several sources, such as mashups created with Yahoo! Pipes.

Extracts from the student blogs demonstrated that students were well on the way to developing the skills, attributes and knowledge required by 'Librarian 2.0' (Partridge, et al., 2010). Nearly all students reported an improvement in their skills at using technology. This was particularly dramatic for a small number of students who persevered despite feeling technically incompetent and fearful, until they were able to achieve success in their tasks. A number of students commented on the difference between practical technical skills and knowledge about the technology, a distinction also noted by Partridge, Lee and Munro (2010).

The need for librarians to engage in lifelong learning was emphasised by Partridge, Lee and Munro (2010). In this assignment students organised their own learning, set learning goals and reported on their progress. A number of them commented that this was the start of a journey of professional development where they would continue exploring new technologies for a long time to come. The enjoyable and challenging nature of the tasks undertaken seems to have contributed to this determination.

By requiring students to explore and evaluate new technologies, the assignment contributed to the development of research or evidence based practice in the continually changing Web 2.0 environment (Partridge, Lee \& Munro, 2010, p. 327). This was particularly evident in the students' investigations of tools for communication, collaboration and teamwork. Most students gained an improved awareness of the tools and their possibilities, although the time available did not allow them to really ascertain which tools were of most relevance for which purpose. Nevertheless, several students expressed the intention of continuing to trial one tool or another for a particular purpose. 
An emphasis on user focus was maintained by asking students to consider how tools might be used in the workplace, for example to assist clients. A number of students commented on what they saw as potential demeaning effects of technology and the danger of losing sight of the real purpose of the profession, to serve users.

The 'Librarian 2.0' attribute of 'business savvy' was evident in the way students had to plan their explorations to ensure that they satisfied all requirements of the assignment and to manage their time in doing so. Many remarked on the difficulty of balancing these factors.

Partridge et al. (2010) enumerated a complex array of personal traits such as enthusiasm, passion, vision, creativity, leadership, adaptability, flexibility, persistence, and resilience (p. 329). Most of the students exhibited one or more of these traits during the course of their Web 2.0 Adventure. The assessment tasks were designed to encourage students to use and hence develop their innate capabilities in these areas.

\section{Conclusion}

Constructive alignment of the course individual learning objectives, the student learning activities and the assessment tasks ensured that student learning as evidenced in their blogs reflects the objectives of the course. Web 2.0 has provided an environment in which the assessment is not just directly linked to the knowledge based learning but embedded in the content delivered.

The course learning objectives were also demonstrated to be closely aligned with the set of skills, knowledge and attributes identified by Partridge, Lee and Munro (2010). as necessary for information professionals in the present and future world of constant change, technological and otherwise. This suggests that the performance of students in the Web 2.0 Adventure is a good indicator of their progress toward these goals. The writings of students in this course demonstrate that they are well on the way to acquiring those capabilities which will make them successful information professionals in the future.

\section{Acknowledgments}

Support for this publication has been provided by the Australian Learning and Teaching Council Ltd, an initiative of the Australian Government Department of Education, Employment and Workplace Relations. The views expressed in this paper do not necessarily reflect the views of the Australian Learning and Teaching Council.

\section{References}

Anderson, P. (2007). What is Web 2.0? Ideas, technologies and implications for education. JISC Technology and Standards Watch.

http: / / www.jisc.ac.uk/publications/ reports / 2007/twweb2.aspx

Beckett, D. \& Hager, P. J. (2002). Life, work and learning: Practice in postmodernity. London: Routledge.

Benbasat, I., Goldstein, D. \& Mead, M. (1987). The case research strategy in studies of information systems. MIS Quarterly, 11(3), 369-386. http: / / dx.doi.org/10.2307/248684 
Bennett, S., Maton, K. \& Kervin, L. (2008). The 'digital natives' debate: A critical review of the evidence. British Journal of Educational Technology, 39(5), 775-786. http: / / dx.doi.org/10.1111/j.1467-8535.2007.00793.x

Biggs, J. B. (2003). Teaching for quality learning at university: What the student does (2nd ed.). Buckingham; Philadelphia, Pa.: Society for Research into Higher Education and Open University Press.

Blowers, H. (2009). WJ hosts 23 Things Summit. [LibraryBytes blog posting, 28 February]. http: / / librarybytes.com/archive/2009_02_01_archive.html

Casey, M. (2005). Working towards a definition of Library 2.0 [LibraryCrunch blog posting 21 October]. http:/ / www.librarycrunch.com/2005/10/working_towards_a_definition_o.html

Casey, M. \& Savastinuk, L. (2006). Library 2.0: Service for the next-generation library. Library Journal. [verified 18 Aug 2011] http:/ / www.libraryjournal.com/article/CA6365200.html

DEST (2002). Employability skills for the future. Australian Government. http: / / www.dest. gov.au/sectors/training_skills/publications_resources/other_publications/

DETYA (2000). Employer satisfaction with graduate skills. Research Report 99(7). Canberra: Evaluations and Investigations Program. Higher Education Division. http: / / www.dest.gov.au/archive/highered/ eippubs / eip99-7 / eip99_7pdf.pdf

Eraut, M. (2002). The interaction between qualifications and work-based learning. In K. Evans \& P. H. L. Unwin (Eds.), Work to learn. London: Kogan Page.

Gross, J. \& Leslie, L. (2010). Learning 2.0: A catalyst for library organisational change. The Electronic Library, 28(5), 657-668. http:/ / dx.doi.org/10.1108/02640471011081942

Henderson, F. \& McWilliams, A. (2008). Enhancing student engagement with industry: A curriculum approach to scaffolding employability skills. Work Integrated Learning (WIL): Transforming futures, WACE Asia Pacific Conference, (pp. 47-60). Sydney: The Australian Collaborative Education Network (ACEN).

Kennedy, G. E., Judd, T. S., Churchward, A., Gray, K. \& Krause, K.-L. (2008). First year students' experiences with technology: Are they really digital natives? Australasian Journal of Educational Technology, 24(1), 108-122. http: / / www.ascilite.org.au/ajet/ajet24/kennedy.html

Kules, B. \& McDaniel, J. (2010). LIS program expectations of incoming students' technology knowledge and skills. Journal of Education for Library and Information Science, 51(4), 222-232.

Laningham, S. (2006). developerWorks Interviews: Tim Berners-Lee. IBM developerWorks, 22 August. [verified 18 Aug 2011] http:/ / www.ibm.com/developerworks/podcast/dwi/cmint082206txt.html

Lewis, L. (2008). Library 2.0: Taking it to the street. VALA 2008 Proceedings. [verified 18 Aug 2011] http:/ / www.vala.org.au/vala2008-proceedings/vala2008-session-1-lewis

McBurney, D. (2001). Research methods (5th ed.). Australia: Wadsworth Thomson Learning.

O'Reilly, T. (2005). What is Web 2.0: Design patterns and business models for the next generation of software. http:/ / www.oreillynet.com/lpt/a/6228

Partridge, H., Lee, J. \& Munro, C. (2010). Becoming "Librarian 2.0": The skills, knowledge, and attributes required by library and information science professionals in a Web 2.0 world (and beyond). Library Trends, 59(1/2), 315-335. http:/ / dx.doi.org/10.1353/lib.2010.0029 
PLCMC (2007). Learning 2.0: 23 things you can do to become web 2.0 savvy. [blog posting, 15 May 2007] http: / / plcmclearning.blogspot.com/

Ramsden, P. (1992). Learning to teach in higher education. London; New York, NY: Routledge.

RMIT University (2011). Graduate attributes [viewed 27 May 2011]

http: / / www.rmit.edu.au/teaching/graduateattributes

Stephens, M. \& Cheetham, W. (2011). The impact and effect of Learning 2.0 programs in Australian academic libraries. New Review of Academic Librarianship, 17(1), 31-63. http: / / dx.doi.org/10.1080/13614533.2011.547414

Talk:Web 2.0 (2011). Wikipedia. http:/ / en.wikipedia.org/wiki/Talk:Web_2.0

Waycott, J., Gray, K., Clerehan, R., Hamilton, M., Richardson, J., Sheard, J. \& Thompson, C. (2010). Implications for academic integrity of using web 2.0 for teaching, learning and assessment in higher education. International Journal for Educational Integrity, 6(2), 8-18. http: / / www.ojs.unisa.edu.au/index.php/IJEI/article/viewFile/699/527

Web 2.0 (2011). Wikipedia. http:/ / en.wikipedia.org/wiki/Web_2.0

Yin, R. K. (2003). Case study research: Design and methods (3rd ed.). Thousand Oaks, CA; London: Sage.

Authors: John Terrell, Lecturer, Information Management School of Business IT \& Logistics

RMIT University, Melbourne, Australia

Email: john.terrell@rmit.edu.au

Dr Joan Richardson, Deputy Head (Learning and Teaching)

School of Business IT \& Logistics

RMIT University, Melbourne, Australia

Dr Margaret Hamilton, Senior Lecturer

School of Computer Science and Information Technology

RMIT University, Melbourne, Australia

Please cite as: Terrell, J., Richardson, J. \& Hamilton, M. (2011). Using Web 2.0 to teach Web 2.0: A case study in aligning teaching, learning and assessment with professional practice. In J. Waycott \& J. Sheard (Eds), Assessing students' Web 2.0 activities in higher education. Australasian Journal of Educational Technology, 27(Special issue, 5), 846-862. http: / / www.ascilite.org.au / ajet/ ajet27 / terrell.html 